\title{
Papers
}

\section{Effectiveness of opportunistic brief interventions for problem drinking in a general hospital setting: systematic review}

\author{
Maria J Emmen, Gerard M Schippers, Gijs Bleijenberg, Hub Wollersheim
}

\begin{abstract}
Objective To determine the effectiveness of opportunistic brief interventions for problem drinking in a general hospital setting. Design Systematic review.

Data sources Medline, PsychInfo, Cochrane Library, reference lists from identified studies and review articles, and contact with experts.

Main outcome measure Change in alcohol consumption. Results Eight studies were retrieved. Most had methodological weaknesses. Only one study, with a relatively intensive intervention and a short follow up period, showed a significantly large reduction in alcohol consumption in the intervention group.

Conclusions Evidence for the effectiveness of opportunistic brief interventions in a general hospital setting for problem drinkers is still inconclusive.
\end{abstract}

\section{Introduction}

Evidence of excessive alcohol consumption is common among patients admitted to hospital for reasons other than drinking. The consumption of more than 14 units a week for women and 21 units a week for men may lead to alcohol dependency and a multitude of medical, psychological, and social problems. Brief psychosocial interventions in general health care, in or out of hospital, can help patients to reduce problem drinking at an early stage.

Brief interventions aimed at problem drinkers are not a type of treatment but a category of interventions with general characteristics that give them conceptual coherence. ${ }^{1}$ Most comprise assessment, advice, and counselling with educational elements and possibly self help manuals or other forms of written information. Professionals other than specialists in substance misuse may deliver the interventions, most of which are aimed at moderate or harm-free drinking as opposed to total abstinence. The interventions may target drinkers who consume hazardous amounts of alcohol or those who exceed the guidelines for safe drinking, low or moderate dependent drinkers, or high, dependent drinkers not reached by conventional treatment services. Brief interventions in medical settings are often opportunisticpatients with non-alcohol related problems are screened and problem drinkers are offered the intervention.

Various reviews and meta-analyses have shown the effectiveness of brief interventions for problem drinking. ${ }^{2-7}$ The most influential study is the World Health Organization randomised clinical trial of brief interventions in primary health care. ${ }^{8}$ Simple advice and brief counselling reduced hazardous and harmful alcohol consumption by both men and women in various healthcare settings and from different cultures.

In all but one review the results from primary healthcare settings and general hospital settings are pooled. ${ }^{6}$ In most European countries, however, these settings are structurally different. General hospitals include specialised somatic outpatient clinics and only treat referred patients, which may lead to bias towards patients with more severe conditions and diseases than in primary care and enables doctors to use stronger arguments when the conditions and diseases may be related to alcohol. Many patients also regard hospital specialists with more authority than the providers of primary health care. The effectiveness of alcohol intervention can therefore differ across settings. We focused on the general hospital setting.

The only meta-analysis concerned with brief interventions and restricted to the primary healthcare setting showed significant reductions in alcohol consumption of $51 \mathrm{~g}$ a week for extended brief interventions (several visits) for women but inconclusive results for men. ${ }^{6}$

We identified and summarised the results of all randomised controlled trials and other well controlled trials that evaluated an opportunistic brief intervention for problem drinking in a general hospital setting to determine whether it reduced alcohol consumption.

\section{Methods}

We searched Medline and PsychInfo databases for articles published between 1966 and 2001. MeSH terms for the Medline search were "alcohol-drinking" or "alcoholism" and "inpatients" or "outpatients" or "internal medicine" or "hospitals-general" or "hospitals-teaching" and "counselling" or "referral-andconsultation" or "psychotherapy" or "prevention-and-control" or "rehabilitation" or "therapy". DE terms for the PsychInfo search were "alcohol rehabilitation" or "alcohol abuse" and "hospitalised patients" or "outpatients" or "medical patients" and "rehabilitation counselling" or "brief psychotherapy" or "alcohol rehabilitation" or "hospital programs".

We searched the reference lists of relevant reviews and contacted experts by email..$^{2-5} 79$ The Current Contents database was searched, and the Cochrane Library was searched for empirical studies on the effectiveness of brief alcohol interventions in a hospital setting.

Relevant titles and abstracts were reviewed in a single reviewer format. Articles were retrieved if they were individually randomised, cluster randomised, or quasirandomised trials and non-randomised trials with equivalent groups at baseline; they focused on an opportunistic brief intervention for problem drinking; they had a control group receiving no intervention; 
they were set in a hospital or specialist outpatient clinic; they had a psychosocial (cognitive or behavioural) intervention; and alcohol consumption was an outcome measure.

\section{Validity assessment and data abstraction}

For each trial we assessed the randomisation status, the blinding of those assessing outcomes, and the loss to follow up. Corresponding authors were allowed to comment on our assessment. All but one replied, and the comments were assimilated into the assessment

For each controlled trial MJE extracted the number and type of patients, the type of intervention and duration, the quality criteria, and the outcome measures using a structured form; GMS checked the data, and any disagreements were resolved by consensus. The first or second authors of the included studies were contacted to obtain additional information and any knowledge of or involvement in current relevant work. The effect sizes were calculated for those studies that provided the number of cases and the means and standard deviations of alcohol consumption at baseline and follow up for both intervention and control groups.

\section{Quantitative data analysis}

We calculated the mean difference (95\% confidence interval) in alcohol consumption as the difference in outcome between the intervention and control groups. Alcohol consumption at follow up was not taken as outcome but, rather, the difference between consumption at baseline and follow up. This corrected for the relatively large individual differences at baseline and the non-randomisation of some of the study designs. We used the standard deviations of consumption at baseline and follow up and the correlation between consumption at these two time points to calculate the standard deviation of change in consumption from baseline. If the correlation was not provided, we estimated it based on studies that did provide the correlation. When several brief interventions were compared with one control group, we calculated the mean difference for each intervention. The study designs and study outcomes were too heterogeneous to allow pooling of data.

\section{Results}

The figure summarises the process for inclusion of studies. Overall, 481 articles were identified. This was reduced to 129 after screening abstracts and keywords for study design. An additional 121 articles were rejected because the intervention was either not opportunistic (75 trials), not psychosocial (2), or not conducted in a hospital setting (36), or the article was a secondary publication (1). ${ }^{10} \mathrm{~A}$ further seven articles were rejected because they had no data on alcohol consumption. Eight articles remained for analysis. ${ }^{11-18}$

\section{Study characteristics}

Table 1 presents the general characteristics of the included trials. They varied in methodological quality, population, intervention, people performing the intervention, and follow up periods.

A total of 1597 problem drinkers were allocated to an opportunistic intervention or usual care. The number of patients per trial ranged from 45 to 428 .

Three of the trials randomised individuals and four randomised clusters of consecutive patients to avoid contamination. One non-randomised, large multicentre study compared patients from four intervention hospitals with those from three matched control hospitals. A series of control measures ensured comparability. Three studies reported blind assessment of

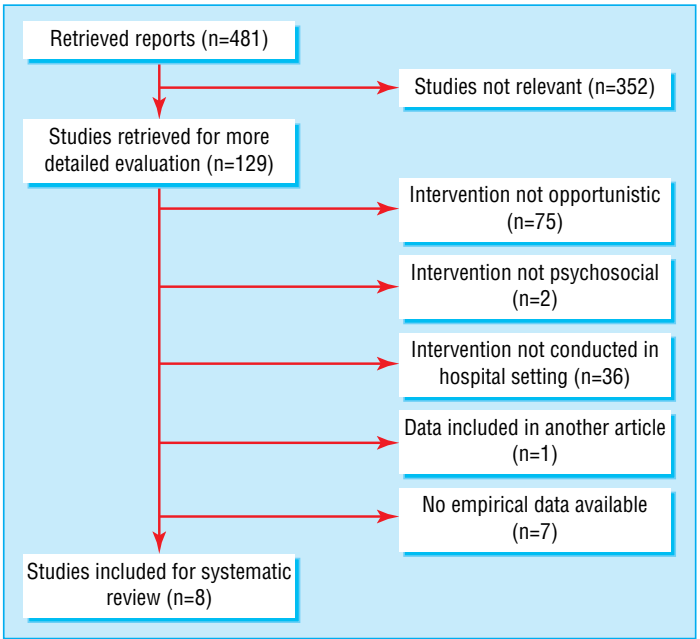

Inclusion of studies for systematic review

outcome. Loss to follow up ranged from $9 \%$ to $50 \%$, with all of the studies excluding these patients from further analysis.

Inclusion criteria were weekly alcohol consumption, problems related to alcohol, evidence of alcohol on screening, a medical record showing a history of alcohol misuse, and an increased concentration of $\gamma$-glutamyltransferase. All of the trials mentioned the exclusion of patients with serious medical or psychiatric disorders. Five studies also excluded patients with a history of advice or treatment for drinking problems or severe alcohol dependency.

Poikolainen made a distinction between very brief interventions (5-20 minutes) and extended brief interventions (several visits). ${ }^{6}$ Three trials examined the effects of very brief interventions involving advice or education on sensible drinking and the health risks associated with heavy drinking. ${ }^{15}{ }^{16}{ }^{18}$ In two of these interventions a booklet was also distributed. ${ }^{19}$ The extended brief interventions lasted from 30 to 75 minutes and mostly consisted of a single counselling session by a professional experienced in the treatment of alcoholism, or brief alcohol related medical advice from the physician, with several follow up sessions. ${ }^{11-14} 17$

The interventions were performed by nurses, ${ }^{14-16}$ psychologists, ${ }^{11}$ physicians, ${ }^{12}$ combinations of these,${ }^{13}{ }^{17}$ or an intervention team specialised in substance misuse. ${ }^{18}$

Trial duration varied from eight weeks to 18 months. In addition to change in alcohol consumption, outcome measures were self reported problems related to alcohol and laboratory variables.

\section{Quantitative data analysis}

We linearly transformed data on alcohol intake into grams a week. In one trial that did not report on the alcohol content of a unit, we assumed an amount of $10 \mathrm{~g} .{ }^{16}$ Calculations based on $8 \mathrm{~g}$ and $14 \mathrm{~g}$ estimates were also made, with no important changes to the results (data not shown).

Table 2 presents the means and standard deviations of change in consumption for the study groups and the mean differences with $95 \%$ confidence intervals. One study gave the correlation between baseline and follow up consumption $(r=0.40) .{ }^{18}$ We used this as the estimate for the other studies. Differences in effects across the studies did not seem to depend on baseline variables.

For three studies we were unable to calculate the mean difference with $95 \%$ confidence interval. One did not report 
Table 1 Characteristics of included studies

\begin{tabular}{|c|c|c|c|c|c|c|c|c|}
\hline \multirow[b]{2}{*}{ Trial } & \multicolumn{4}{|c|}{ Participants } & \multicolumn{2}{|l|}{ Intervention } & \multicolumn{2}{|c|}{ Study quality } \\
\hline & Type; inclusion criteria & Sex & $\begin{array}{l}\text { No randomised } \\
\text { (No completed } \\
\text { follow up) }\end{array}$ & $\begin{array}{l}\text { Mean (SD) intake at } \\
\text { baseline (g/wk) }\end{array}$ & Active & $\begin{array}{c}\text { Follow up } \\
\text { (months) }\end{array}$ & $\begin{array}{l}\text { Blind } \\
\text { assessment } \\
\text { of outcome }\end{array}$ & $\begin{array}{l}\text { Loss to } \\
\text { follow up } \\
(\%)\end{array}$ \\
\hline \multicolumn{9}{|c|}{ Individually randomised: } \\
\hline Elvy et al ${ }^{11}$ & $\begin{array}{l}\text { Inpatients, three } \\
\text { orthopaedic and two } \\
\text { surgical wards; Canterbury } \\
\text { alcoholism screening test } \\
\text { score } \geq 3^{23}\end{array}$ & $\begin{array}{l}\text { Men and } \\
\text { women }\end{array}$ & $\begin{array}{l}\text { Intervention } 84(61) \text {, } \\
\text { control } 114(86)\end{array}$ & Not available & $\begin{array}{l}\text { Confrontational interview } \\
\text { by psychologist about self } \\
\text { reported drinking problems, } \\
\text { and attempt at referral }\end{array}$ & $12 ; 18$ & No & $26 ; 39$ \\
\hline$\overline{\text { Maheswaran et al }{ }^{12}}$ & $\begin{array}{l}\text { Outpatients, hypertension } \\
\text { clinic; >20 units of alcohol } \\
\text { weekly }\end{array}$ & Men & $\begin{array}{l}\text { Intervention } 23(20) \text {, } \\
\text { control } 22(21)\end{array}$ & $\begin{array}{l}\text { Intervention } 600 \\
(252) ; \text { control } 551 \\
(228)\end{array}$ & $\begin{array}{l}\text { Brief advice (10-15 } \\
\text { minutes) by clinic } \\
\text { physician about risks from } \\
\text { consumption and benefits } \\
\text { from reduction (better } \\
\text { control over blood } \\
\text { pressure) and four follow } \\
\text { up sessions }\end{array}$ & 2 & No & 9 \\
\hline $\begin{array}{l}\text { Persson and } \\
\text { Magnusson }{ }^{13}\end{array}$ & $\begin{array}{l}\text { Outpatients, five somatic } \\
\text { outpatient clinics; males } \\
>20 \text { units of alcohol } \\
\text { weekly, females }>15 \text { units } \\
\text { weekly, } \\
\gamma \text {-glutamyltransferase } \\
>36 \mathrm{IU} / \mathrm{L}\end{array}$ & $\begin{array}{l}\text { Men and } \\
\text { women }\end{array}$ & $\begin{array}{l}\text { Intervention } 36 \text { (27), } \\
\text { control } 42 \text { (not } \\
\text { available) }\end{array}$ & $\begin{array}{l}\text { Intervention } 179 \\
(n=106) ; \text { control } 160 \\
(140)\end{array}$ & $\begin{array}{l}\text { Biofeedback on laboratory } \\
\text { tests monthly by nurse and } \\
\text { every third month by } \\
\text { doctor for } 12 \text { months }\end{array}$ & 12 & No & Not available \\
\hline \multicolumn{9}{|l|}{ Cluster randomised: } \\
\hline Chick et al ${ }^{14}$ & $\begin{array}{l}\text { Inpatients, four medical } \\
\text { wards; }>50 \text { units of alcohol } \\
\text { weekly or bingeing or } \\
\text { alcohol related problems }\end{array}$ & Men & $\begin{array}{l}\text { Intervention } 78(69) \text {, } \\
\text { control } 78(64)\end{array}$ & $\begin{array}{l}\text { Intervention } 552 \\
\text { (345.56); control } \\
552(364.80)\end{array}$ & $\begin{array}{l}\text { Counselling (60 minutes): } \\
\text { booklet and discussion } \\
\text { with experienced nurse }\end{array}$ & 12 & Yes & 15 \\
\hline $\begin{array}{r}\text { Rowland and } \\
\text { Maynard }^{15}\end{array}$ & $\begin{array}{l}\text { Inpatients, four medical } \\
\text { and five orthopaedic wards; } \\
\text { males }>36 \text { units of alcohol } \\
\text { weekly, females }>24 \text { units } \\
\text { weekly or bingeing or } \\
\text { modified CAGE score }>2\end{array}$ & $\begin{array}{l}\text { Men and } \\
\text { women }\end{array}$ & $\begin{array}{l}\text { Intervention } 214 \\
\text { (88) control } 214 \\
\text { (126) }\end{array}$ & $\begin{array}{l}\text { Intervention 409; } \\
\text { control } 443 \text { (not } \\
\text { available) }\end{array}$ & $\begin{array}{l}\text { Audiovisual presentation of } \\
\text { information on alcohol by } \\
\text { nursing staff or researcher } \\
\text { and booklet }\end{array}$ & 12 & No & 50 \\
\hline Watson $^{16}$ & $\begin{array}{l}\text { Inpatients, medical, } \\
\text { surgical, orthopaedic, and } \\
\text { short stay wards; males } \\
>21 \text { units of alcohol } \\
\text { weekly, females } 14 \text { units } \\
\text { weekly }\end{array}$ & $\begin{array}{l}\text { Men and } \\
\text { women in all } \\
\text { groups }\end{array}$ & $\begin{array}{l}\text { Intervention } 37 \text { (27), } \\
\text { control } 47(31) ; \\
\text { intervention } 34(23) \text {, } \\
\text { control } 47(31) ; \\
\text { intervention } 32(21) \text {, } \\
\text { control } 47 \text { (31) }\end{array}$ & $\begin{array}{l}\text { Intervention } 457 \\
\text { (576), control } 452 \\
(429) ; \text { intervention } \\
410(210), \text { control } \\
452(429) ; \\
\text { intervention } 446 \\
\text { (308), control } 452 \\
\text { (429) }\end{array}$ & $\begin{array}{l}\text { Provided by nurse in } \\
\text { general hospital: booklet; } \\
\text { brief advice (10-15 } \\
\text { minutes); booklet and brief } \\
\text { advice (10-15 minutes) }\end{array}$ & $12 ; 12 ; 12$ & Yes; yes; yes & $31 ; 33 ; 34$ \\
\hline Heather et $\mathrm{al}^{17}$ & $\begin{array}{l}\text { Inpatients, different wards } \\
\text { from four teaching } \\
\text { hospitals; }>28 \text { units of } \\
\text { alcohol weekly or bingeing }\end{array}$ & $\begin{array}{l}\text { Men in all } \\
\text { groups }\end{array}$ & $\begin{array}{l}\text { Intervention } 63(43) \text {, } \\
\text { control } 48(33) ; \\
\text { intervention } 63(47) \text {, } \\
\text { control } 48 \text { (33) }\end{array}$ & $\begin{array}{l}\text { Intervention } 541 \\
\text { (216), control } 434 \\
\text { (297); intervention } \\
495 \text { (275); control } \\
434 \text { (297) }\end{array}$ & $\begin{array}{l}\text { Provided by psychologist } \\
\text { or experienced nurse: skills } \\
\text { based counselling* ( } 30-40 \\
\text { minutes); brief motivational } \\
\text { interview† ( } 30-40 \text { minutes) }\end{array}$ & $6 ; 6$ & Yes; yes & $32 ; 28$ \\
\hline \multicolumn{9}{|l|}{ Non-randomised: } \\
\hline Welte et $\mathrm{al}^{18}$ & $\begin{array}{l}\text { Inpatients, four hospitals; } \\
\text { drinking in last month and } \\
\text { either CAGE score }>1 \text { or } \\
\text { history of alcohol misuse } \\
\text { in medical record }\end{array}$ & $\begin{array}{l}\text { Men and } \\
\text { women }\end{array}$ & $\begin{array}{l}\text { Intervention } 67(56) \text {, } \\
\text { control } 301(220)\end{array}$ & $\begin{array}{l}\text { Intervention } 238 \\
\text { (357); control } 278 \\
(565)\end{array}$ & $\begin{array}{l}\text { Risk reduction intervention: } \\
\text { factual information on risks } \\
\text { of alcohol use and } \\
\text { suggestions to reduce } \\
\text { intake by intervention team } \\
\text { specialised in substance } \\
\text { misuse }\end{array}$ & 6 & No & 27 \\
\hline
\end{tabular}

CAGE=Feeling that you should Cut down on your drinking, Anger at criticism of drinking, Guilt about drinking, and use of "Eye-opener" drink in morning. ${ }^{24}$

*Investigation of drinking pattern, recommended limits and alcohol effects; instruction on self monitoring, tips for reduction, instruction on how to identify and cope with high risk situations discussion of alternative activities to change drinking; booklet.

†Assessment of recent drinking; exploration of positive and negative aspects of heavy drinking; information on effects of alcohol; exploration of patient concerns.

standard deviations. ${ }^{15}$ Another stated that the intervention had no effect on alcohol consumption, without presentation of relevant data. ${ }^{11}$ The authors were contacted, but the data could not be retrieved and were therefore not provided. One study failed to collect data on change in alcohol consumption in the control group. ${ }^{13}$ One study showed a significantly larger reduction in weekly alcohol consumption in the intervention group (mean difference $-309 \mathrm{~g},-470 \mathrm{~g}$ to $-148 \mathrm{~g}$ ). ${ }^{12}$ The other studies found no significant effects.

\section{Discussion}

Evidence for the effectiveness of opportunistic brief interventions in a general hospital setting for problem drinkers is still inconclusive. In our systematic review only one study, with a short follow up period, found a significant effect. ${ }^{12}$

\section{Strengths and weaknesses}

One strength of our review is that we considered one outcome measure-change in alcohol consumption. The methodological quality of the selected trials was reasonable, although most showed a relatively large loss to follow up. This can lead to attrition bias but is often unavoidable in addiction research.

The small number of studies precluded the exploration of reasons for heterogeneity. Only two of the trials were conducted on outpatients, and one produced clearly positive results. ${ }^{12}$ Except for one trial, all of those in which an experienced nurse presented the intervention produced only small effects..$^{15}{ }^{16}$ The 
Table 2 Outcome results for included studies

\begin{tabular}{|c|c|c|c|c|c|}
\hline \multirow[b]{2}{*}{ Trial } & \multicolumn{2}{|c|}{$\begin{array}{c}\text { Change (SD) in alcohol consumption from baseline } \\
\text { (g/week) }\end{array}$} & \multirow{2}{*}{$\begin{array}{l}\text { Mean difference } \\
\quad(95 \% \mathrm{Cl})^{\star}\end{array}$} & \multirow[b]{2}{*}{ Alcohol related problems } & \multirow[b]{2}{*}{ Changes in laboratory values } \\
\hline & Intervention group & Control group & & & \\
\hline Elvy et al ${ }^{11}$ & Not available & Not available & No significant difference & $\begin{array}{l}\text { Intervention group improved } \\
\text { significantly more than control group }\end{array}$ & $\begin{array}{l}\gamma \text {-glutamyltransferase, mean cell } \\
\text { volume, aspartate aminotransferase, } \\
\text { blood alcohol level: no data reported }\end{array}$ \\
\hline Maheswaran et al ${ }^{12}$ & $-284(276)$ & $25(250)$ & $-309(-470$ to -148$)$ & Not available & $\begin{array}{l}\gamma \text {-glutamyltransferase reduced, } \\
\text { intervention group } 21 \% \text {; control group } \\
0 \% \text { : significant difference, aspartate } \\
\text { aminotransferase, mean cell volume: } \\
\text { no significant difference }\end{array}$ \\
\hline $\begin{array}{l}\text { Persson and } \\
\text { Magnusson }^{13}\end{array}$ & $-62(113)$ & Not available & Not available & $\begin{array}{l}\text { Days of sickness reduced: intervention } \\
\text { group, } 65 \% \text {; control group, } 27 \% \text {. } \\
\text { Significant difference }\end{array}$ & $\begin{array}{l}\gamma \text {-glutamyltransferase, mean cell } \\
\text { volume, aspartate aminotransferase, } \\
\text { alanine aminotransferase: no } \\
\text { significant difference }\end{array}$ \\
\hline Chick et $\mathrm{al}^{14}$ & $-296(375)$ & $-272(366)$ & -24 (-150 to 102$)$ & $\begin{array}{l}\text { Reduced: intervention group } 41 \% \text {; } \\
\text { control group } 14 \% \text {. Significant } \\
\text { difference }\end{array}$ & $\begin{array}{l}\gamma \text {-glutamyltransferase: significant } \\
\text { reduction in intervention group, mean } \\
\text { cell volume: no significant difference }\end{array}$ \\
\hline Rowland and Maynard ${ }^{15}$ & -96 (not available) & -72.50 (not available) & $\begin{array}{l}\text {-23.5; no significant } \\
\text { difference }\end{array}$ & $\begin{array}{l}\text { Reduced health problems: intervention } \\
\text { group } 31 \% \text {; control group } 22 \% \text {. } \\
\text { Significant difference }\end{array}$ & Not available \\
\hline \multicolumn{6}{|l|}{ Watson ${ }^{16}$ : } \\
\hline Booklet & $-120(530)$ & $-147(414)$ & 27 (-220 to 274) & No significant difference & $\begin{array}{l}\gamma \text {-glutamyltransferase, aspartate } \\
\text { aminotransferase and mean cell } \\
\text { volume: no significant difference }\end{array}$ \\
\hline Advice & $-121(288)$ & $-147(414)$ & 26 (-161 to 213) & No significant difference & $\begin{array}{l}\gamma \text {-glutamyltransferase, aspartate } \\
\text { aminotransferase and mean cell } \\
\text { volume: no significant difference }\end{array}$ \\
\hline Booklet and advice & $-206(286)$ & $-147(414)$ & $-59(-249$ to 131$)$ & No significant difference & $\begin{array}{l}\gamma \text {-glutamyltransferase, aspartate } \\
\text { aminotransferase and mean cell } \\
\text { volume: no significant difference }\end{array}$ \\
\hline \multicolumn{6}{|l|}{ Heather et $\mathrm{al}^{17}$ : } \\
\hline $\begin{array}{l}\text { Skills based } \\
\text { counselling }\end{array}$ & $-186(255)$ & $-127(280)$ & -59 (-181 to 63) & Not available & Not available \\
\hline $\begin{array}{l}\text { Brief motivational } \\
\text { interview }\end{array}$ & $-219(270)$ & $-127(280)$ & -92 (-215 to 31) & Not available & Not available \\
\hline Welte et $\mathrm{al}^{18}$ & $-139(327)$ & $-119(545)$ & $-20(-132$ to 92$)$ & No significant difference & Not available \\
\hline
\end{tabular}

* Mean difference in changes in alcohol consumption from baseline in grams a week for control group versus intervention group (95\% confidence interval).

two trials involving a doctor or a psychologist during intervention produced larger effects. ${ }^{12} 17$

Given the small number of studies and the extreme results reported in one, we could not determine publication bias with a funnel plot. We tried to include unpublished work by contacting the experts but cannot be sure we identified all trials.

\section{Other studies}

Our results do not concur with the mostly positive results reported elsewhere for brief alcohol interventions in general health care..$^{2-5} 78$ Such results may be partly due to the pooling of data from hospital and primary healthcare settings. A review of brief interventions in only primary care did not show strong evidence of an effect. ${ }^{6}$

\section{Possible explanations}

The large treatment effect in the only study reporting positive results can be explained in two ways ${ }^{12}$ Firstly, a relatively intensive intervention was conducted in male outpatients with hypertension in which during every visit the physician emphasised the importance of lowering alcohol consumption to control blood pressure. Secondly, the control group was told to continue with their usual consumption of alcohol, which was not the case in the other studies.

The other trials found a significant reduction in alcohol consumption in the control groups. Comparable reductions have been observed in the control groups of other alcohol intervention studies. ${ }^{78}$ The reason for this is unclear. This finding can be expected as a consequence of regression to the mean, ${ }^{620} 21$ but may also reflect a reactive effect of the assessment. ${ }^{7} 1622$

\section{What is already known on this topic}

The effectiveness of brief interventions for problem drinkers is well established

The results for primary healthcare settings are positive, but less conclusive

\section{What this study adds}

Evidence for the effectiveness of opportunistic brief interventions in general hospitals for problem drinkers is inconclusive

Assessment may make patients more aware of the potentially harmful effects of alcohol consumption.

\section{Future research}

New randomised controlled trials using blind assessment of outcome and intention to treat analyses should be encouraged. In particular non-assessment control groups, as in a Solomon four group design, should be considered to evaluate the impact of assessment alone.

We thank RJPM Scholten for advice on the data analysis.

Contributors: MJE conducted the search, extracted the data, evaluated the study quality, analysed the data, and wrote the paper. GMS contributed to the research design, review of the methods, quality evaluation, and data analysis; he will act as guarantor for the paper. HW and GB reviewed the results, advised on the interpretation of the data, and made substantial comments on the text. The guarantor accepts full responsibility for the con- 
duct of the study, had access to the data, and controlled the decision to publish.

Funding: Netherlands Organisation for Health Research and Development. Competing interests: None declared.

Ethical approval: Not required.

1 Heather N. Brief intervention strategies. In: Hester RK, Miller WR, eds. Handbook of alcoholism treatment approaches: effective alternatives. Needham Heights, MA: Allyn and Bacon, 1995:105-22

2 Freemantle N, Gill P, Godfrey C, Long A, Richards C, Sheldon TA, et al. Brief interven tions and alcohol use. Qual Health Care 1993;2:267-73.

3 Kahan M, Wilson L, Becker L. Effectiveness of physician-based interventions with problem drinkers: a review. CMAJ 1995;152:851-9.

4 Wilk AI, Jensen NM, Havighurst TC. Meta-analysis of randomized control trials addressing brief interventions in heavy alcohol drinkers.J Gen Intern Med 1997;12:27483.

5 Moyer A, Finney JW, Swearingen CE, Vergun P. Brief interventions for alcohol problems: a meta-analytic review of controlled investigations in treatment-seeking and problems: a meta-analytic review of controlled investigations
non-treatment-seeking populations. Addiction 2002;97:279-92

6 Poikolainen K. Effectiveness of brief interventions to reduce alcohol intake in primary health care populations: a meta-analysis. Prev Med 1999;28:503-9

7 Bien TH, Miller WR, Tonigan JS. Brief interventions for alcohol problems: a review. Addiction 1993;88:315-35.

8 Babor TF, Grant M. Programme on substance abuse. Project on identification and management of alcohol related problems. Report on phase II: a randomized clinical trial of brief intervention in primary health care. Geneva, Switzerland: World Health Organization, 1992

9 Miller WR, Brown JM, Simpson TL, Handmaker NS, Bien TH, Luckie LF, et al. What works? A methodological analysis of the alcohol treatment outcome literature. In: Hester RK, Miller WR, eds. Handbook of alcoholism treatment approaches: effective alternatives. Needham Heights, MA: Allyn and Bacon, 1995:12-44.

10 Persson J. Early intervention in patients with excessive alcohol consumption: a controlPersson J. Early intervention in patients with
led study. Alcohol Alcohol Suppl 1991;1:473-6.

11 Elvy GA, Wells JE, Baird KA. Attempted referral as intervention for problem drinking in the general hospital. Br J Addict 1988;83:83-9.

12 Maheswaran R, Beevers M, Beevers DG. Effectiveness of advice to reduce alcohol consumption in hypertensive patients. Hypertension 1992;19:79-84.

13 Persson J, Magnusson PH. Early intervention in patients with excessive consumption of alcohol: a controlled study. Alcohol 1989;6:403-8.
14 Chick J, Lloyd G, Crombie E. Counselling problem drinkers in medical wards: a controlled study. BMJ 1985;290:965-7.

15 Rowland N, Maynard AK. Standardized and alcohol education: a hit or miss affair? Health Promotion Int 1993;8:5-12.

16 Watson HE. A study of minimal interventions for problem drinkers in acute care settings. Int J Nurs Stud 1999;36:425-34.

17 Heather N, Rollnick S, Bell A, Richmond R. Effects of brief counselling among male heavy drinkers identified on general hospital wards. Drug Alcohol Rev 1996;15:29-38.

18 Welte JW, Perry P, Longabaugh R, Clifford PR. An outcome evaluation of hospital-based early intervention program. Addiction 1998;93:573-81.

19 Health Education Authority. That's the limit: a guide to sensible drinking. London: HEA, 1989.

20 Anderson P, Scott E. The effect of general practitioners' advice to heavy drinking men. Br J Addict 1992;87:891-900.

21 Richmond R, Heather N, Wodak A, Kehoe L, Webster I. Controlled evaluation of a general practice-based brief intervention for excessive drinking. Addiction 1995;90:11932.

22 Clifford PR, Maisto SA. Subject reactivity effects and alcohol treatment outcome research.J Stud Alcohol 2000;61:787-93.

23 Elvy GA, Wells JE. The Canterbury alcoholism screening test (CAST): a detection instrument for use with hospitalised patients. NZ Med J 1984:97:111-5.

24 Ewing JA. Detecting alcoholism. The CAGE questionnaire. JAMA 1984;252:1905-7.

(Accepted 13 November 2003)

doi $10.1136 /$ bmj.37956.562130.EE

Amsterdam Institute for Addiction Research, PO Box 39071001 AS Amsterdam, Netherlands

Maria J Emmen PhD student

Gerard M Schippers professor of psychology of addictive behaviours

Expert Centre for Chronic Fatigue, University Medical Centre St Radboud, PO

Box 91016500 HB Nijmegen, Netherlands

Gijs Bleijenberg professor of psychology of chronic fatigue

Department of Quality Care, UMC St Radboud Nijmegen

Hub Wollersheim associate professor

Correspondence to: M J Emmen

emmen@aiar.nl 